\section{Developing Educational Technologies In School Technology Education}

\author{
M.Kh. Shomirzayev \\ Phd, Associate Professor, Termez State University \\ Termez, Uzbekistan
}

\author{
G OPEN ACCESS \\ The American Journal \\ of Engineering And \\ Technology \\ JULY 2020 \\ Page No.: 51-57 \\ Volume-II Issue-VII \\ PUBLISHED: 30 JULY 2020 \\ www.usajournalshub.com/inde \\ x.php/tajet \\ Copyright: Original content \\ from this work may be used \\ under the terms of the \\ Creative Commons Attribution \\ 4.0 licence.
}

\title{
Abstract
}

In the article, the author highlights the content of solving some practical topics in labor and vocational education in school technology education, such as mathematics, physics, biology, as well as practical issues related to agriculture and technology.

Keywords: school, educator, student, education, upbringing, technology, method, developmental education, practice, problem, skill, profession, efficiency.

\section{Introduction}

The List of Pedagogical Terms defines the terms "development" and "developmental education" as follows:

"Development is the process of formation of an individual from birth to the end of his life" [11, P.166].

"Developmental education is the process by which every student moves from one quality stage to another through education; the teaching process taking into account the capabilities of each student " $[1,132]$. Book, Pedagogy: "1000 Answers to 1000 questions" $[2,136]$, describes the characteristics of developmental education as follows: "Developmental education focuses on empowering and realizing students' inner potential. In developmental education, training is more commonly used. The trainings provide students with the skills to master certain knowledge, to apply them effectively in practice, 
in the process, it helps them realize their full potential. Today, there is experience in the effective use of presentations in the application of developmental education in the system of continuing education. This method helps students to develop a creative approach to the organization of educational activities, self-study, independent learning" [11, 164-165].

\section{The Main Findings And Results}

\section{"To provide new knowledge in the field of "Technology", to use the method of training in the formation of labor skills.}

Technology classes also give students an understanding of mechanisms. Such lessons can be organized using trainings as follows. The teacher begins the lesson with a brainstorming session: "What is the detail?" Students' answers are written on the board, underlined, and general rules are developed: "Integral parts of machines and mechanisms that cannot be divided into other components are called details." The teacher then divides the participants into three subgroups, the first group "What is a bullet?", The second group "What is a shaft?", And the third group "What is a spindle?" Ask them to answer the questions for 2 minutes and have one student from each group speak. After the students have answered, the teacher uses the machine and drawings to provide detailed information about the bullet, shaft, and spindle.

There will be games in between to keep students from getting tired. The teacher throws the ball to the students and asks the meaning of something, and the student has to answer immediately and throw the ball back. For example, "What is a typical detail?", "What is a special detail?", "What is a bullet?" and h. At the end of the game, "What is the mechanism?" and takes the unanswered ball and starts the next training session. The teacher asks the students, "What do you mean by a mechanism?" The answers are written on the board and a generalized description is developed: "Mechanical devices consisting of leading and guiding links and transmitting motion are called mechanisms" [11, 164-165].

Then the second part of the lesson begins. The teacher divides the participants I into two groups and asks, "What do you mean by a car?" And "What are the parts of a car?" asks them to answer questions like When the groups are ready, the answers are discussed, and the teacher corrects the students' mistakes, makes additions, and concludes the lesson.

Students who actively participate in the class will be assessed at the end of the class. The group with the most correct answers to the questions is the winner. Specially designed emblems can be used to identify the winning team during the lesson. Specially prepared marks are given to groups and are collected at the end of the lesson, on the basis of which points are awarded. It is important to note that when students work in small groups, the teacher should guide them and help them correct their mistakes.

The method of determining the future on the basis of available data. It helps to visualize the future appearance of an object, mechanism, or machine, and to determine how it will work and be used, based on historical and current information. For example, you can use tables in the following forms: 


\begin{tabular}{|l|l|l|l|}
\hline Name & $\begin{array}{l}\text { There was, } \\
\text { there was } \\
\text { (historical } \\
\text { information) }\end{array}$ & Available now & Future status \\
\hline Pen & $\begin{array}{l}\text { Straw, feathers, } \\
\text { ink pens }\end{array}$ & Ball pens & Electronic pens \\
\hline Hour & $\begin{array}{l}\text { Sand, } \\
\text { mechanical, } \\
\text { electronic }\end{array}$ & $\begin{array}{l}\text { Mechanical, } \\
\text { electronic }\end{array}$ & $?$ \\
\hline TV set & Lampali & Chips & $?$ \\
\hline $\begin{array}{l}\text { Computer } \\
\text { monitor }\end{array}$ & Electron beam & $\begin{array}{l}\text { Electron beam, } \\
\text { plasma }\end{array}$ & $?$ \\
\hline$\ldots$ & $\ldots$ & $\ldots$ & $?$ \\
\hline
\end{tabular}

"If I ..." method. Students will be asked to provide feedback on how they, as a professional, can solve problems in this area. For example, "If I were a car designer ... I would have created a car" (If I were a car designer, I would have created a car that can walk in the mountains. To do this, I would use a helicopter to drive a car). "If I were an aircraft designer ... I would create an airplane" [7, P.42] and so on. The advantage of this method is that it develops students' imagination, comparison and imagination.

\section{Use of practical mathematical problems in "Technology" lessons.}

The subject of "Technology" in general secondary schools, the solution of practical mathematical problems in vocational education classes in vocational colleges is one of the factors that ensure the rapid and easy mastery of this subject by students. Especially when some topics related to labor and vocational education are linked to subjects such as mathematics, physics, biology, as well as to the solution of problems in the field of agriculture and technology, students are able to interrelate these disciplines. Convenient opportunities will be created for them to learn. To this end, we recommend the following few issues.

Issue 1. What is the minimum cross-section of the wood, ie the diameter or length of the circle, to make a square beam with sides of $15 \mathrm{~cm}$ ? (Figure 4).

Given: $A B=B C=C D=D A=15 \mathrm{sm}$.

Need to find: $B D=d=$ ?

A

B

Solution: According to the Pythagorean theorem:

$\mathrm{d}=\sqrt{a^{2}+a^{2}}=\mathrm{a} \sqrt{2}$

Here, $a=15 \mathrm{~cm}$.

Putting it in place: $d=15 \times 1.41=21,15 \sim 21,2$

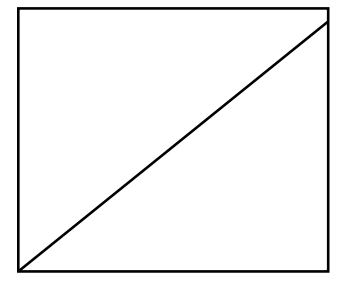

Figure 4

This means that to make a square beam with a side of $15 \mathrm{~cm}$, the diameter of the timber must be at least $21.2 \mathrm{~cm}$. But usually the diameter of the wood is not the same 
along the length. Therefore, to determine the required diameter, it is necessary to find the circumference $C$ of the wood. In this case, the formula $C=2 \mathrm{R}$ is used. Assuming that the edges of the circle pass through points $B, D$, as in Figure 4, then BD becomes the diameter of the cross section. From this, if we replace the numbers, we get $C=66.5 \mathrm{~cm}$. This means that a wooden fence with a circumference of $66.5 \mathrm{~cm}$ and a side of $15 \mathrm{~cm}$ can be made into a square beam. This problem can be applied to 8th grade geometry and 7 th8th grade technology classes.

Here are some practical questions.

Issue 2. A $3 \mathrm{~cm}$ thick board was brought. How many planks will be needed to floor a room with sides $4 \mathrm{~m} 5 \mathrm{~m}=20$ sqm? Keep in mind that an average of $5 \mathrm{~mm}$ of wood is cut into pieces (6th grade math, 8th grade geometry, 5th-7th grade labor education).

Issue 3. How much electricity does a $100 \mathrm{~W}$ light bulb use if it stays on for 2 hours? Calculate this for a month and a year. How much electricity would it take if ten light bulbs were on for so long? If the average cost of $1 \mathrm{~kW}$ of electricity is 143 soums, how much will be paid for the above electricity consumption? (5th grade mathematics, 6th grade physics, 5-6-7th grade technology science).

Issue 4. How can a piece of material with dimensions of $3 \mathrm{~m} 3 \mathrm{~m}=9$ sq.m be divided into four pieces to form three equal squares (grades 5-6, mathematics, technology)?

Issue 5. The average yield of cotton is 3 quintals per hectare. How many acres of cotton should be planted to produce a ton of "white gold"? 20; 25; 30; Find the answer to the question for 35 cases (grades 5-6; basics of agriculture).

Issue 6. There are 75,000 cotton seedlings per hectare. If one gram of cotton is not harvested in each bush, how much cotton is left on 200 hectares? (Grades 5-6 Mathematics; Fundamentals of Agriculture).

Issue 7. It is known that cotton is processed into cotton fiber, seeds and cotton wool. The mass of the obtained cotton fiber is $35.5-36 \%$ of the mass of cotton, and the mass of seeds is $60-61.5 \%$. One ton of cotton can produce 300 meters of cotton, $100-110$ $\mathrm{kg}$ of vegetable oil, $200-250 \mathrm{~kg}$ of cotton. With this information in mind, complete the table below (Grades 5-6; Basics of Agriculture).

\begin{tabular}{|l|l|l|l|l|l|}
\hline Quantiry & $\begin{array}{l}\text { Tola } \\
(\mathrm{kg})\end{array}$ & $\begin{array}{l}\text { Chigit } \\
(\mathrm{kg})\end{array}$ & $\begin{array}{l}\text { Yarn } \\
(\mathrm{m})\end{array}$ & $\begin{array}{l}\text { Vegetabl } \\
\text { e oil } \\
(\mathrm{kg})\end{array}$ & $\begin{array}{l}\text { Kunjara } \\
(\mathrm{kg})\end{array}$ \\
\hline $1 \mathrm{t}$. & $355-360$ & $600-610$ & 300 & $100-110$ & $200-250$ \\
\hline $5 \mathrm{t}$. & & & & & \\
\hline $100 \mathrm{t}$. & & & & & \\
\hline $1000 \mathrm{t}$. & & & & & \\
\hline $1000000 \mathrm{t}$. & & & & & \\
\hline $3000000 \mathrm{t}$. & & & & & \\
\hline
\end{tabular}

Issue 8. According to agro-technical requirements, for long-term storage of grain, its moisture (condensation state) should be $14 \%$. If the moisture content of freshly harvested grain is $22 \%$, what is the percentage decrease in mass when it is dried to condensation (Grades 5-6; Basics of Agriculture, Technology)?

Issue 9. How much should be taken from plants with $80 \%$ and $35 \%$ moisture to 
produce a blue mass with a moisture content of $75 \%$ during silage pressing (grades $5-6$; basics of agriculture, technology)?

Issue 10. The length of the rod of a metal structure is $5 \mathrm{dm}$, and each rod extends by $2 \mathrm{dm}$. Find the length of the 7 rods (Fig. 5. 9th grade algebra; technique, technology science)?

Issue 11. Under favorable conditions, one bacterium doubles in one minute. What is the number of bacteria in 7 minutes (Figure 6. Grade 9 algebra; biology, technology)?
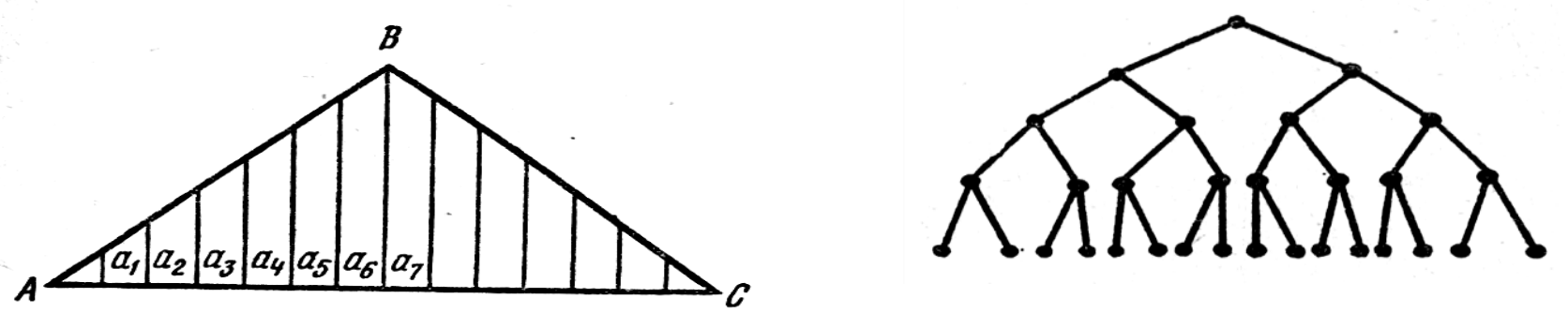

Figure Figure 6

Issue 12. As you know, the cutting speed on a lathe is calculated by the formula. In this case, $D$ is the diameter of the workpiece (in $\mathrm{mm}$ ), $\mathrm{n}$ is the number of revolutions per minute of the part. Construct a connection graph for a lathe-revolver, assuming that the variable $\mathrm{n}$ is a constant.

Assume that $D=70 \mathrm{~mm}$ and draw a graph for the cases where Figure 6 is $\mathrm{n}=70$, $105,158,220,330,494$ (Grades 8-9 Algebra and Vocational Education).

There are many such issues. By using them regularly in labor and vocational education classes, it is possible to increase students' interest in science and professions, and to convincingly demonstrate how different subjects can be applied in life and technology.

From the above, it is clear that educating students is a difficult task. One of the most difficult tasks of a teacher is to make all students active in the classroom, taking into account the individual characteristics of each student. It is important to remember that the student's activity does not increase spontaneously, but is the result of a conscious attitude. Since activism is the result of consciousness, it requires the coordination of the content, form of organization, methods and means of implementation of educational work. The teacher must consciously increase the students' interest in reading.

"Human life is like a journey from one place to another. This road is flat, smooth, and has a lot of ups and downs. We are the fastest growing people in the world today. The mountain road requires courage, bravery and vigilance," said one of our favorite poets, Hero of Uzbekistan E.Vakhidov. In the same way, educating students and guiding them to choose a profession is a difficult task.

It should be noted that, unlike other subjects in secondary schools, there is a great opportunity to develop students' understanding of the field of production by increasing the activity of students in the subject "Technology". Because in "Technology" classes, theoretical education is closely linked with practical education. This allows students to work independently and demonstrate their abilities to the best of their ability. Students enjoy seeing their own creations, comparing them with those of their peers, being proud of their accomplishments, and correcting any shortcomings. This will be the first step in developing students into independent individuals. In organizing such activities, it is 
important that the teacher's skills, in particular, the form and methods of teaching, depending on the nature of the lesson.

Recently, great changes have taken place in the field of education in our country. This can be seen in the directives for reforming the education system, educational standards, curricula and literature, as well as in the construction of new educational institutions.

However, there are some issues that need to be addressed. One of them is to develop and implement more effective forms and methods of teaching students to activate their cognitive activity, independent thinking and ability to work in the classroom. Improving the content of education, using a variety of active teaching methods has become a requirement of the times. The outcome of a teacher's work in the educational process largely depends on the activity of the students. To do this, the teacher must look for innovations, show examples of initiative and creativity. Therefore, it is necessary to improve the lessons of "Technology", including the theoretical and practical training of students activation of practical activities related to active work in them

However, there are some issues that need to be addressed. One of them is to develop and implement more effective forms and methods of teaching students to activate their cognitive activity, independent thinking and ability to work in the classroom.

Improving the content of education, using a variety of active teaching methods has become a requirement of the times. The outcome of a teacher's work in the educational process largely depends on the activity of the students. To do this, the teacher must look for innovations, show examples of initiative and creativity. Therefore, it is important to improve the lessons of "Technology", to activate the theoretical and practical work of students, to develop in them the skills of active work.

\section{Conclusions}

Based on the above considerations, the following can be concluded:

1. Technology classes have a great opportunity to acquaint students with the main links and areas of production, to prepare them for independent living and to guide them to choose different professions. Therefore, it is the professional duty of every teacher of "Technology" to achieve a thorough organizational, methodological, scientific, technical, ideological and political lessons of "Technology".

2. The formation of students' cognitive activity, the formation of positive and creative work skills in the lessons of "Technology" is a complex process carried out through the most important pedagogical, psychological, physiological and technicaltechnological factors. It is important to remember that there is no substitute for a teacher. Therefore, first of all, the teacher must constantly improve his professional skills, scientific and methodological level.

3. It should be noted that the activation of students' cognitive activity in educational work, the acquisition of skills to perform practical work with understanding - is a gradual and long-lasting process of pedagogical activity. That is, the student is suddenly active, fast, and active will not be perfect. Therefore, there is no point in rushing through these matters. You just have to be more discriminating with the help you render toward other people. All the great scholars of different times have said that teaching young people to 
live and think in a new way is always a requirement of the times. It is important to increase student engagement. Because if a student is active in the educational process, he will be an excellent and social student. A student brought up in this spirit can become an active worker, in other words, an active member of society, a citizen, while maintaining and even developing this quality in the future.

4. Simple, ie traditional forms and methods of teaching to educate students and increase their activity in the process of "Technology" in general secondary schools as well as the use of innovative pedagogical technologies gives good results. In order to increase the effectiveness of this work, it is necessary to carefully plan the stages of its implementation. Usually, it is not interesting for them to give information about what they know to anyone. That's why it's more fun for us to tell students what they want to know.

\section{References:}

1. Babanskiy Yu.K. Modern general education teaching methods. -T.: "Teacher", 1990. -132 p.

2. Yuldashev J.G., Usmanov S.A. Fundamentals of pedagogical technology. -T.: Teacher, 2004. - 136 p.

3. Karimov I. The use of interactive teaching methods in labor education classes. $-\mathrm{T}$.: RTM, 2009. - 124 p.

4. Rakhmatillayev A., Shomirzayev M.X. et al. Dynamics of the effectiveness of interactive methods. - T .: "Avu press-consultant", 2015. -60 p.

5. Sharipov Sh.S. and oth. Technology: Textbook, 7 p. -T.: "Sharq", 2017.

6. Sattorova Z. and oth. Technology: Textbook for 9th grade. -T.: "O'zbekiston", 2019. - 160 p.

7. Shomirzayev M.X. Ways to increase the effectiveness of technology teaching. -T.: "Gold print edition", 2019. - 42 p.

8. Shomirzayev M.X. Genesis of formation and development technology of Uzbek national handicrafts. - T.: "Yangi Nashr", 2019. - 52 p.

9. Shomirzayev M.X. Innovative processes in Uzbek national handicrafts. - T.: "New edition", 2019. - 88 p.

10. Shomirzayev M.X. Spectral-variable components of Uzbek national handicrafts. - T.: "Yangi Nashr", 2019. - 27 p.

11. Shomirzayev M.X., Karimov I.I. Innovative pedagogical technologies in teaching technology. - T.: "University", 2020. - 164-167 p. 